\title{
LIFE AND DEATH AT SUNRISE
}

\author{
NEAR DOGBURY GATE, I 867
}

THE hills uncap their tops

Of woodland, pasture, copse,

And look on the layers of mist

At their foot that still persist:

They are like awakened sleepers on one elbow lifted,

Who gaze around to learn if things during night have shifted.

A waggon creaks up from the fog

With a laboured leisurely jog;

Then a horseman from off the hill-tip

Comes clapping down into the dip;

While woodlarks, finches, sparrows, try to entune at one time, And cocks and hens and cows and bulls take up the chime.

With a shouldered basket and flagon

A man meets the one with the waggon,

And both the men halt of long use.

'Well,' the waggoner says, 'what's the news ?'

'- 'Tis a boy this time. You've just met the doctor trotting back. She's doing very well. And we think we shall call him "Jack."

'And what have you got covered there?'

He nods to the waggon and mare.

'Oh, a coffin for old John Thinn:

We are just going to put him in.'

'- So he's gone at last. He always had a good constitution.'

'- He was ninety-odd. He could call up the French Revolution.' 